\title{
Evaluation of groundwater renewability in the Henan Plains, China
}

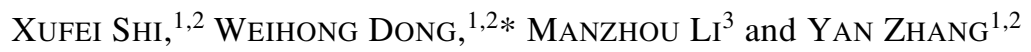 \\ ${ }^{1}$ Key Laboratory of Groundwater Resources and Environment, Ministry of Education, Jilin University, \\ Jiefang Road, Changchun 130021, P.R. China \\ ${ }^{2}$ Institute of Water Resources and Environment, Jilin University, Jiefang Road, Changchun 130021, P.R. China \\ ${ }^{3}$ Institute of Geological Environment Monitoring of Henan Province, Jinshui East Road, Zhenzhou 450016, P.R. China
}

(Received August 15, 2011; Accepted December 5, 2011)

\begin{abstract}
The sustainability of groundwater resources in the Henan Plains, located in the eastern portion of central China, has been threatened by both increasing industrial and agricultural pumping and periods of drought occurring since the 1990s. Therefore, there is an urgent need to improve water resources management in the Henan Plains. However, the recharge and annual renewal rate are very difficult to be calculated when based only on traditional hydrogeological methods because of inadequate hydrometeorologic data. In this study, tritium concentrations in groundwater and reconstructed ${ }^{3} \mathrm{H}$ concentration time series from 1953 2009 in precipitation were used to determine the annual groundwater renewal rate. The ${ }^{3} \mathrm{H}$ concentrations mostly ranged from 2.91 to $40.30 \mathrm{TU}$ in the shallow groundwater with a mean ${ }^{3} \mathrm{H}$ concentration of 19.13 TU, which suggested that the shallow groundwater was recharged from modern precipitation after 1953 in the study area. Three exceptionally low ${ }^{3} \mathrm{H}$ concentration(less than $1 \mathrm{TU}$ ) wells were sampled in Xinxiang, Puyang and Zhengyang which indicated that those wells contained deep old groundwater recharge before 1953 as a result of over-pumping. High renewal rates (more than 4\%/a) of groundwater are located mainly in the recharge areas such as the Yellow River nearby and the pediments of Taihang Mountain, Songqi Mountain, Funiu Mountain, Dabie Mountain, where the groundwater extraction volume could be increased. Moderate renewal rates (2 4\%/a) of groundwater are mainly in the runoff areas where the groundwater extraction volume can be kept at current levels. Low renewal rates (1 2\%/a) of groundwater are located mainly in the discharge areas in the eastern regions of Nanle, Puyang, Shangqiu, Luyi where the groundwater extraction volume should be reduced. The lowest renewal rates of (less than 1\%/a) groundwater are in Fanxian, Xinxiang, Yongcheng, Zhengyang and Xixian, where the groundwater extraction volume should be restricted.
\end{abstract}

Keywords: renewal rate, ${ }^{3} \mathrm{H}$, shallow groundwater, reconstruction of tritium in precipitation, the Henan Plains, China

\section{INTRODUCTION}

Shallow groundwater is the important water resources for industry, agriculture and domestic use (Ministry of Water Resources Division, Nanjing Hydraulic Research Institute, 2004) in the Henan Plains of China. Nowadays, the sustainability of groundwater resources is threatened by both increasing industrial and agricultural pumping and periods of drought occurring since the 1990s. Because of over pumping of shallow groundwater, water shortage has already occurred in Henan Plains and a series of environmental geological problems such as regional groundwater level decline (Lan and Liu, 2005), land subsidence (Miao, 2010) and ground fissure (Gao, 2008) have emerged in many cities in Henan Plains, such as Anyang, Hebi, Puyang, Xinxiang, Zhengzhou, Zhengyang and Xixian (Institute of Geological Environment Monitoring of Henan Province, 2006; Institute of

*Corresponding author (e-mail: dongweihong@jlu.edu.cn)

Copyright (c) 2012 by The Geochemical Society of Japan.
Geological Survey of Henan Province, 2007). Therefore, there is an urgent need to improve water resources management in Henan Plains. Hydrogeological information such as total resources and renewal rate of groundwater (i.e., the ratio between the annual recharge and the total reserve) is essential for improving water resources management (Le Gal La Salle et al., 2001).

Estimations of the recharge and annual renewal rate are very difficult, when based only on traditional hydrogeological methods such as water budget, groundwater balance or Darcy's law, because these methods often require large volumes of hydrometeorologic data collected over considerable time span and hydrological parameters which are generally inadequate or unreliable in many regions (Wood and Imes, 1995; Wood and Sanford, 1995; Wood, 1999; Flint et al., 2002; Edmunds et al., 2002). Thus, isotope tracers have been proven to be extremely useful in the research of groundwater renewability (Le Gal La Salle et al., 2001; Ma and Hou, 2005). In recent years, ${ }^{3} \mathrm{H}$ is considered to be an ideal tracer in the ground water renewal rate calculation, because ${ }^{3} \mathrm{H}$ participates in water cycle as a component of water molecule 
(Clark and Fritz, 1997; Gat et al., 2000). Tritium's halflife allows it to be used as a dating tool for relatively young water, i.e., water recharged less than 50 years ago (Clark and Fritz, 1997). However, observations of tritium concentration in precipitation are generally scarce. So, the utilization of tritium concentration is strongly limited by our knowledge of the natural distribution of tritium in precipitation over both space and time. Fortunately, the methods of reconstructing the tritium concentration time series in precipitation are well documented (Weiss and Roether, 1980; Guan, 1986; Lian, 1990; Doney et al., 1992; Celle-Jeanton et al., 2001; Ba and Xu, 2010; Zhang et al., 2011). A simpler approach to obtain isotopic data for a location where no data is available would be to interpolate existing data from other neighboring locations. Despite its lack of the physical basis that a numerical model provides, interpolation has been frequently used in environmental sciences. Isotopic hydrology literature has several examples to offer, utilizing a large variety of interpolation methods (e.g., Lian, 1990; Longinelli and Selmo, 2003; Gibson et al., 2005; Lykoudis et al., 2010). All these methods are able to produce highresolution gridded isotopic data sets as well as an estimate of the associated uncertainty (Lykoudis et al., 2010).

In this study, we reconstructed the tritium time series of precipitation in Henan Plains and calculated the renewal rate of shallow groundwater using ${ }^{3} \mathrm{H}$ as a tracer. The results of this study can provide theoretical documentation for improving water resources management in Henan Plains.

\section{STUdy AREA AND REgional HydRogeOlogical SETTING}

The Henan Plains is located at $112^{\circ} 31^{\prime} \sim 116^{\circ} 40^{\prime} \mathrm{E}$, $32^{\circ} 00^{\prime} \sim 36^{\circ} 12^{\prime} \mathrm{N}$, in the east of Henan Province, in middle eastern portion of China, with an area of about $8.53 \times$ $10^{4} \mathrm{~km}^{2}$. The Henan Plains is surrounded by mountains in the northwest, west and south and vast plains in the east (Fig. 1). Former Quaternary outcrops exist mainly in mountain areas, where fissure and karst formations are developed. Former Quaternary outcrops are Cambrian and Ordovician limestone of the Paleozoic with Permian and Carboniferous sandstone and shale secondly in the areas of Taihang Mountain and Songqi Mountain. In the areas of Tongbai Mountain and Dabie Mountain, the former Quaternary outcrops are metamorphic rocks of Archean, Proterozoic and Paleozoic.

The Henan Plains is overlain widely by unconsolidated formations of the Quaternary period, whose thickness follows a gradual increase from less than $100 \mathrm{~m}$ in pediment in the mountains to more than $180 \mathrm{~m}$ in the middle plain, and even more than $400 \mathrm{~m}$ in some places of eastern part of Henan Plains. The aquifer media consists

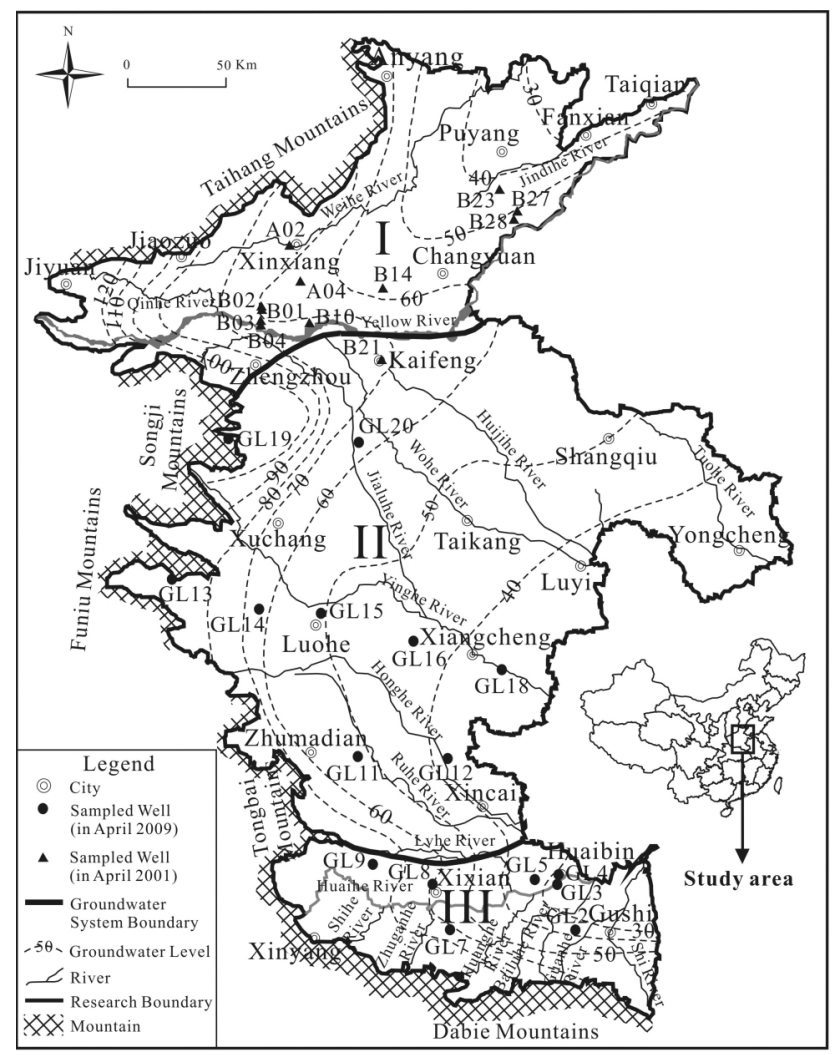

Fig. 1. Study area and groundwater sampling locations of ${ }^{3} H$ samples.

mainly of sandy gravel and sand in the pediments of Taihang Mountain, Funiu Mountain and Songqi Mountain. The pediment of Dabie Mountain is cut into gullies by tributaries of Huaihe River. So the hypsography is remarkable in the pediment of Dabie Mountain. In addition, the aquifer media consists of medium-coarse sand and small amount of silt in the east of Puyang-KaifengXuchang and the west of Shangqiu-ZhechengXiangcheng. The aquifer media consists mainly of silt, fine sand and mild clay in the east of ShangqiuZhecheng-Xiangcheng and Xincai, Xixian Huaibin areas.

According to the characteristics of aquifer media and the burial settings of groundwater, the unconsolidated formation of the Quaternary in the Henan Plains is classified as a shallow-buried aquifer (the confining bed depth is about $40 \sim 160 \mathrm{~m}$ ), middle-buried aquifer (the lower confining bed depth 100 400 m) and deep-buried aquifer (the lower confining bed depth is $300 \sim 500 \mathrm{~m}$ ). Most of the groundwater used in industry and agriculture comes from the shallow aquifer, for example, the pumping rate from shallow aquifer was $89.68 \times 10^{8} \mathrm{~m}^{3} / \mathrm{a}$ which was $85.56 \%$ of the total pumping rate $\left(104.81 \times 10^{8} \mathrm{~m}^{3} / \mathrm{a}\right)$ in 1997 in the Henan Plains (Ministry of Water Resources Division, Nanjing Hydraulic Research Institute, 2004). 
Table 1. The content of ${ }^{3} \mathrm{H}$ in the groundwater samples

\begin{tabular}{|c|c|c|c|}
\hline Sample No. & ${ }^{3} \mathrm{H}(\mathrm{TU})$ & Sample No. & ${ }^{3} \mathrm{H}(\mathrm{TU})$ \\
\hline GL2 & 23.00 & GL19 & 15.57 \\
\hline GL3 & 27.26 & GL20 & 20.10 \\
\hline GL4 & 38.23 & A02 & $8.07 *$ \\
\hline GL5 & 29.3 & A04 & $0^{*}$ \\
\hline GL7 & 11.62 & B01 & $3.89 *$ \\
\hline GL8 & 5.48 & B02 & $5.83^{*}$ \\
\hline GL9 & 0 & B03 & $11.11^{*}$ \\
\hline GL11 & 29.80 & B04 & $23.43^{*}$ \\
\hline GL12 & 23.57 & B10 & $40.30^{*}$ \\
\hline GL13 & 15.61 & B14 & $14.00^{*}$ \\
\hline GL14 & 33.47 & B21 & $12.71^{*}$ \\
\hline GL15 & 15.63 & B23 & $2.91 *$ \\
\hline GL16 & 33.47 & B27 & $3.18^{*}$ \\
\hline GL18 & 30.80 & B28 & $0.60 *$ \\
\hline
\end{tabular}

*Calculated value.

Thus, the objective of this groundwater renewal rate evaluation is focused on shallow groundwater resources. The shallow groundwater system can be divided into three subsystems. They are northern plain groundwater system (I), central plain groundwater system (II), and southern plain groundwater system (III), according to the characteristics of the groundwater flow and the watershed which it belongs to (Fig. 1).

Precipitation is the main source of recharge for shallow groundwater, with small amounts of recharge from the bedrock fissure water and the karstic water in pediment of mountains in Henan Plains. Otherwise, groundwater nearby the Yellow River can be recharged by the Yellow River water by the lateral seepage because the Yellow River is a ground suspended river whose water level is higher than groundwater level. According to Cui et al. (2004), only groundwater within $5.0 \sim 23.0 \mathrm{~km}$ from the banks of the Yellow River can be recharged by the water from the Yellow River. Otherwise, pumping is the main discharge of shallow groundwater in the Henan Plains, besides a small amount of evaporation, runoff to the down gradient and leakage to the deep-buried aquifer.

Groundwater flow in the shallow aquifer is influenced primarily by regional topography. Hydraulic head in the shallow groundwater decreases from west to east (i.e., from the pediment of mountains to the eastern plain) on the whole. However, in the nearby of watersheds, groundwater flows from the watershed to the two opposite directions separated by watersheds and both of the flow directions are right-angled with the watershed (Fig. 1). The hydraulic gradient and permeability of aquifer both follow a gradual decrease trend from the pediment of mountains to the eastern plain.

\section{Field Sampling and Analytical Methods}

Sixteen shallow groundwater samples (Fig. 1) were collected for ${ }^{3} \mathrm{H}$ concentration measurements from domestic wells in April, 2009. Renewal of the water column was obtained by half hour pumping before sampling in order to obtain representative water of the aquifer. The tritium concentrations (Table 1) were measured by counting of scintillations of phase liquid in State Key Laboratory of Earthquake Dynamics in Institute of Geology of China Earthquake Administration and expressed in tritium unit (TU) with an uncertainty of $\pm 0.5 \mathrm{TU}$.

Considering that the tritium concentration is influenced only by radioactive decay with no reaction with aquifer media (Tian et al., 2007), 12 additional tritium concentration data were collected to complement the tritium data in the northern plain groundwater subsystem which were sampled in April, 2001. To allow comparison of tritium concentration in different years, the ${ }^{3} \mathrm{H}$ concentration in shallow groundwater samples which were sampled in 2001 must be regulated to 2009 using radioactive decay formula (Eq. (1)) before calculating the renewal rate.

$$
A_{2009}=A_{2001} e^{-\lambda \times 8}
$$

where $A_{2001}$ is the tritium concentration of groundwater in 2001; $A_{2009}$ is the calculated tritium concentration of groundwater in $2009 ; \lambda$ is the radioactive constant (5.58 $\left.\times 10^{-2} \mathrm{a}^{-1}\right)$.

\section{METHODS}

\section{Model of well-mixed reservoir}

Well-mixed reservoir model, applied by Le Gal La Salle et al. (2001), assumes that a complete mixing of groundwater issued from successive recharge episodes occurs within the aquifer. This model can be used in Henan Plain based on the following two reasons. One is that the shallow aquifer media consists mainly of sandy gravel, medium-coarse sand on the whole except for silt, fine sand and mild clay in a small part of study area; therefore, it is easy for the shallow groundwater to be recharged by precipitation. The other is that the shallow groundwater flows very slowly because of the small hydraulic gradient (about 1/3300 on average) in Henan Plains; so a mixing of groundwater issued from successive recharge episodes can be occurred within the aquifer.

For the model of a well-mixed reservoir with annual time steps and the radioactive decay of ${ }^{3} \mathrm{H}$ in solution, the annual ${ }^{3} \mathrm{H}$ concentration of groundwater is calculated as follows:

$$
A_{g i}=\left(1-R_{i}\right) A_{g i-1} e^{-\lambda}+R_{i} A_{o i}
$$


Table 2. Recorded ${ }^{3} \mathrm{H}$ concentration of precipitation in Zhengzhou station by IAEA

\begin{tabular}{lllllll}
\hline Year & 1986 & 1987 & 1988 & 1989 & 1990 & 1991 \\
\hline${ }^{3} \mathrm{H}(\mathrm{TU})$ & 38.15 & 52.74 & 19.78 & 25.38 & 19.53 & 20.10 \\
\hline
\end{tabular}

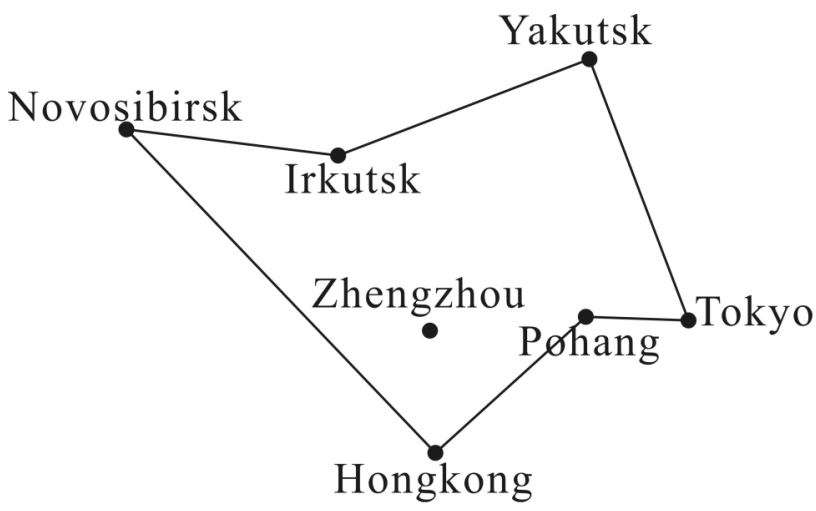

Fig. 2. Distribution of monitoring stations around Zhengzhou station.

where $A_{g}$ is the ${ }^{3} \mathrm{H}$ concentration of groundwater; $A_{o}$ is the ${ }^{3} \mathrm{H}$ concentration of the input water; $\lambda$ is the radioactive constant $\left(5.58 \times 10^{-2} \mathrm{a}^{-1}\right) ; i$ is the time by year, ranging from 0 to 56 (corresponding to the calendar year 20091953); $R_{i}$ is the annual renewal rate. For the model, the annual recharge is firstly assumed to be proportional to the annual rainfall. Therefore, the annual renewal rate, $R_{i}$ is given by the mean renewal rate, $R$ weighted by the annual rainfall, $P_{i}$, so $R_{i}=R P_{i} / P_{m}$, where $P_{m}$ is the annual mean rainfall.

The ${ }^{3} \mathrm{H}$ concentration of the input water (precipitation) $A_{o}$ is $10 \mathrm{TU}$ before 1953 (Wang, 1991), then

$$
A_{g 1953}=10 /(\lambda / R+1)
$$

\section{Reconstruction of tritium time series in precipitation}

As the main recharge of shallow groundwater in the Henan Plains, precipitation is the main input source of ${ }^{3} \mathrm{H}$ in groundwater. According to the locations of the monitoring stations for ${ }^{3} \mathrm{H}$ concentration in precipitation in China sited by International Atomic Energy Agency (IAEA), the ${ }^{3} \mathrm{H}$ concentration in precipitation at Zhengzhou station was chosen to represent the ${ }^{3} \mathrm{H}$ concentration of precipitation in study area. Zhengzhou station is the only station in study area. However, since only records of ${ }^{3} \mathrm{H}$ concentrations of precipitation between 1986 1991 at Zhengzhou station exist (Table 2), the ${ }^{3} \mathrm{H}$ concentration of precipitation in other years between 1953 2009 must be reconstructed in order to calculate
Table 3. Coefficients for the interpolation equation of ${ }^{3} \mathrm{H}$ concentration in precipitation and correlation coefficients

\begin{tabular}{rcrrc}
\hline Year & \multicolumn{1}{c}{$A_{i}$} & \multicolumn{1}{c}{$B_{i}$} & \multicolumn{1}{c}{$C_{i}$} & Correlation coeff. \\
\hline 1969 & -2.536 & 10.870 & 60.610 & 0.957 \\
1970 & -1.755 & 9.235 & 9.082 & 0.876 \\
1971 & -3.211 & 7.880 & 230.395 & 0.812 \\
1972 & -2.129 & 4.430 & 172.023 & 0.933 \\
1973 & -0.387 & 5.532 & -94.117 & 0.961 \\
1974 & -1.127 & 5.303 & 9.739 & 0.949 \\
1975 & -1.088 & 4.522 & 22.044 & 0.942 \\
1976 & -1.085 & 3.428 & 49.895 & 0.954 \\
\hline
\end{tabular}

Table 4. The reconstructed ${ }^{3} H$ concentration time series in precipitation from 1953 to 2009

\begin{tabular}{rrrr}
\hline Year & ${ }^{3} \mathrm{H}(\mathrm{TU})$ & Year & ${ }^{3} \mathrm{H}(\mathrm{TU})$ \\
\hline 1953 & 24.07 & 1982 & 36.75 \\
1954 & 182.53 & 1983 & 32.33 \\
1955 & 33.13 & 1984 & 30.18 \\
1956 & 119.56 & 1985 & 29.51 \\
1957 & 79.64 & 1986 & $38.15^{*}$ \\
1958 & 364.12 & 1987 & $52.74^{*}$ \\
1959 & 281.92 & 1988 & $19.78^{*}$ \\
1960 & 102.84 & 1989 & $25.38^{*}$ \\
1961 & 145.91 & 1990 & $19.53^{*}$ \\
1962 & 609.88 & 1991 & $20.10^{*}$ \\
1963 & 1766.69 & 1992 & 20.81 \\
1964 & 937.57 & 1993 & 19.27 \\
1965 & 479.96 & 1994 & 20.37 \\
1966 & 348.14 & 1995 & 17.85 \\
1967 & 204.69 & 1996 & 18.13 \\
1968 & 139.60 & 1997 & 21.63 \\
1969 & 149.80 & 1998 & 20.11 \\
1970 & 130.27 & 1999 & 19.10 \\
1971 & 139.06 & 2000 & 21.75 \\
1972 & 83.87 & 2001 & 18.93 \\
1973 & 53.97 & 2002 & 17.06 \\
1974 & 65.78 & 2003 & 16.92 \\
1975 & 55.40 & 2004 & 17.12 \\
1976 & 45.60 & 2005 & 19.17 \\
1977 & 52.90 & 2006 & 15.79 \\
1978 & 52.72 & 2007 & 18.97 \\
1979 & 38.17 & 2008 & 8.21 \\
1980 & 38.11 & 2009 & 7.00 \\
1981 & 41.48 & & \\
\hline & & & \\
\hline
\end{tabular}

* Observed data at Zhengzhou station.

the renewal rate of groundwater.

Interpolation is a kind of multivariate statistical analysis method which can effectively analyze particular spatial distribution and variation trends of an attribute data (Shaw, 1977; Sun et al., 2003). In this study, taking the position of monitoring stations and the recorded ${ }^{3} \mathrm{H}$ concentrations in precipitation into account, we used inter- 


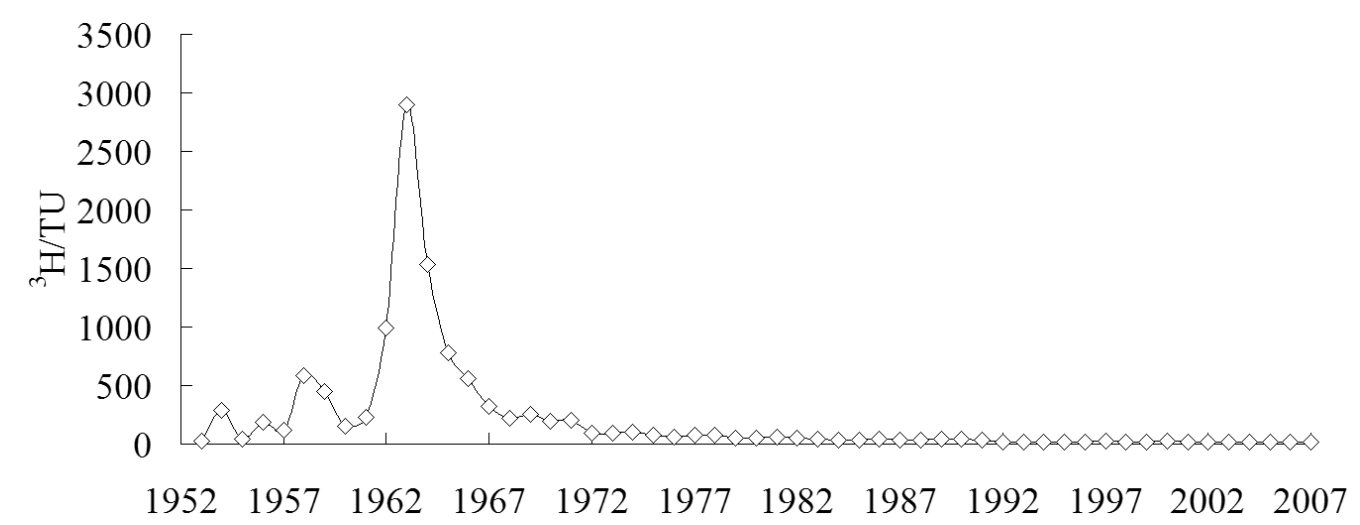

Fig. 3. ${ }^{3} \mathrm{H}$ concentration time series of precipitation at Ottawa station.

polation (Eq. (4)) to calculate the ${ }^{3} \mathrm{H}$ concentrations in precipitation from 1969 to 1976 at Zhengzhou station.

$$
T_{i}(x, y)=A_{i} x+B_{i} y+C_{i}
$$

where $x$ and $y$ are longitude and latitude of the monitoring station respectively; $T_{i}(x, y)$ is the ${ }^{3} \mathrm{H}$ concentration of precipitation in No. $i$ year at the point of $(x, y) ; A_{i}, B_{i}$ and $C_{i}$ are the coefficients in the interpolation equation.

First, we calculated the coefficients: $A_{i}, B_{i}$ and $C_{i}$ in interpolation equation for ${ }^{3} \mathrm{H}$ concentration of precipitation between 1969 1976 at Zhengzhou station by the Least square method. In the calculation, the longitude and latitude coordinates and the ${ }^{3} \mathrm{H}$ concentrations in precipitation from 1969 to 1976 are those at Pohang station, Tokyo station, Irkutsk station, Novosibirsk station, Yakutsk station and Hong Kong station. Those monitoring stations are distributed around Zhengzhou station (Fig. 2). The correlation coefficient test of significance showed that the correlativity was high between observed data and calculated data for every year (Table 3 ).

Substituting $A_{i}, B_{i}$ and $C_{i}$ (Table 3 ) and the coordination by longitude and latitude of Zhengzhou station into Eq. (4) produced the ${ }^{3} \mathrm{H}$ concentration of precipitation between 1969 1976 at Zhengzhou station (shown in Table 4).

The ${ }^{3} \mathrm{H}$ concentrations in precipitation for 1953 1968, 1977 1985 and 1992 2007 at Zhengzhou station (Table 4) were reconstructed on linear regression equations (Eq. (5)) by data at Ottawa where ${ }^{3} \mathrm{H}$ was measured in precipitation for long period from 1953 to 2007 (Fig. 3). The ${ }^{3} \mathrm{H}$ concentrations in precipitation (including recorded and reconstructed between 1969 1976) at Zhengzhou station had a distinct relativity with that at Ottawa station (the correlation coefficient was 0.97 ).

$$
y=0.6064 x+8.0747, \quad R=0.97
$$

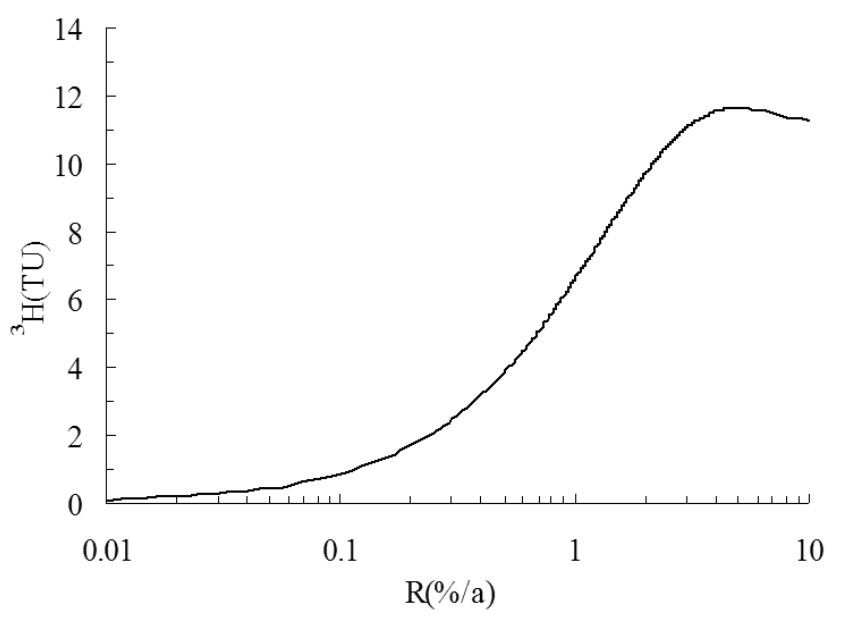

Fig. 4. Curve of renewal rate vs. ${ }^{3} \mathrm{H}$ in groundwater.

where $x$ is the ${ }^{3} \mathrm{H}$ concentration of precipitation at Ottawa station; $y$ is that at Zhengzhou station; $R$ is correlation coefficient.

The range of ${ }^{3} \mathrm{H}$ concentration time series for precipitation in Ottawa station is from 1953 to 2007 with a lack of data from 2008 2009. So the linear regression equation (Eq. (6)) between ${ }^{3} \mathrm{H}$ concentration and time at Zhengzhou station (the correlation coefficient was 0.86 ) was constructed to calculate the ${ }^{3} \mathrm{H}$ concentration of precipitation by the least square method at Zhengzhou station for years 2008 2009 (Table 4).

$$
y=-1.2109 t+2439.7, \quad R=0.86
$$

where $t$ is the time; $y$ is the ${ }^{3} \mathrm{H}$ concentration of precipitation at Zhengzhou station; $R$ is correlation coefficient.

Calculation of renewal rate

For a series of given $R$ values (for example $R=1 \sim 100$ ), 
Table 5. Renewal rate of the groundwater

\begin{tabular}{ll}
\hline Sample No. & Renewal rate (\%/a) \\
\hline GL2 & 4.91 \\
GL3 & 4.91 \\
GL4 & 4.91 \\
GL5 & 4.91 \\
GL7 & 4.91 \\
GL8 & 0.78 \\
GL9 & 0.01 \\
GL11 & 4.91 \\
GL12 & 4.91 \\
GL13 & 4.91 \\
GL14 & 4.91 \\
GL15 & 4.91 \\
GL16 & 4.91 \\
GL18 & 4.91 \\
GL19 & 4.91 \\
GL20 & 4.91 \\
A02 & 1.39 \\
A04 & 0.02 \\
B01 & 0.51 \\
B02 & 0.85 \\
B03 & 3.07 \\
B04 & 4.91 \\
B10 & 4.91 \\
B14 & 4.91 \\
B21 & 4.91 \\
B23 & 0.36 \\
B27 & 0.40 \\
B28 & 0.07 \\
\hline &
\end{tabular}

a series of $A_{g}$ can be calculated accordingly by Eq. (2) and Eq. (3). Then the $A_{g} \sim R$ curve of the study area was made to calculate the groundwater renewal rate on the basis of the ${ }^{3} \mathrm{H}$ concentration of groundwater samples.

According to the above method, the relation curves of ${ }^{3} \mathrm{H}$ output concentration $\left(A_{g}\right)$ and mean renewal rate of shallow groundwater in 2009 in the study area were constructed following the model of a well-mixed reservoir (Fig. 4).

The groundwater annual renewal rate (shown in Table 5) of every sample can be determined by the curve of Fig. 4 according to the ${ }^{3} \mathrm{H}$ concentration of each groundwater sample.

\section{RESULTS AND DISCUSSION}

\section{${ }^{3} \mathrm{H}$ concentration in shallow groundwater}

The natural background activity of ${ }^{3} \mathrm{H}$ in precipitation prior to 1952 was about $10 \mathrm{TU}$ (Wang, 1991). As a result of radioactive decay, groundwater derived from precipitation that fell before the onset of atmospheric testing of nuclear weapons in 1953 (pre-bomb) would have contained not more than $0.45 \mathrm{TU}$ in 2009 . In the study area, the ${ }^{3} \mathrm{H}$ concentrations mostly ranged from 2.91 to

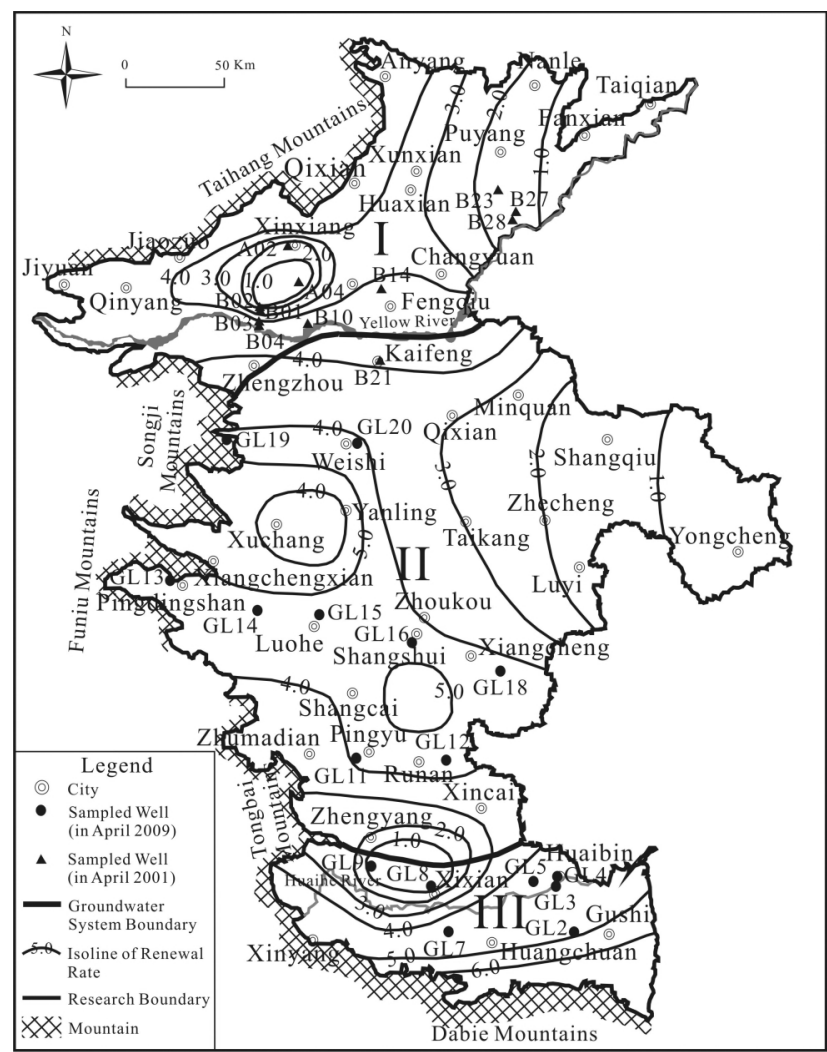

Fig. 5. The isogram of groundwater renewal rate.

$40.30 \mathrm{TU}$ in the shallow groundwater with a mean ${ }^{3} \mathrm{H}$ concentration of $19.13 \mathrm{TU}$ which was much greater than $0.45 \mathrm{TU}$. The range of ${ }^{3} \mathrm{H}$ concentration in groundwater suggested that the shallow groundwater was recharged from modern precipitation after 1953 in study area. Three exceptionally low values (less than $1 \mathrm{TU}$ ) were measured in three samples: GL9, A04 and B28 located in Zhengyang, Xinxiang and Puyang respectively. According to Ministry of Water Resources Division, Nanjing Hydraulic Research Institute (2004), Xinxiang city had the highest rates of both groundwater pumping $(27.22 \times$ $\left.10^{8} \mathrm{~m}^{3} / \mathrm{a}\right)$ and module of groundwater yield $\left(33 \times 10^{4} \mathrm{~m}^{3} /\right.$ $\mathrm{km}^{2} \cdot \mathrm{a}$ ) in 2003 in Henan Plains. And according to Zhang et al. (2001), land subsidence was very severe in Puyang because of over pumping of groundwater, the accumulated ground subsidence had been 41 57 mm from 1997 to 2001 , with the area of land subsidence at about 140 $\mathrm{Km}^{2}$ in 1997. Therefore, those low values of ${ }^{3} \mathrm{H}$ concentration in groundwater could indicate that the wells contained deep old groundwater recharge from before 1953 resulting from over-pumping of shallow groundwater.

\section{Estimates of groundwater renewal rate}

The calculated renewal rate of shallow groundwater in Henan Plains varies between $0.01 \sim 4.91 \%$, with a mean 
of about $3.42 \%$ (Table 5). This relatively large range of renewal rate in shallow groundwater is probably due to the variability of the hydraulic conductivity and the recharge of deep groundwater with low ${ }^{3} \mathrm{H}$ concentration under the influence of over pumping in some low renewal rate locations.

In this paper, the interpolation in space is used to construct the isogram of renewal rate, based on calculated renewal rate for 28 samples in order to understand the spatial distribution law of the renewal rate in shallow groundwater (Fig. 5).

On the whole, the renewal rate in shallow groundwater decreases from the pediments of Taihang Mountain, Funiu Mountain and Songqi Mountain to the eastern plain in the direction of groundwater flow. Groundwaters in the pediments of mountains and near the Yellow River are characterized by high renewal rates of more than 4\%/a. In the east and northeast along Nanle, Puyang city and Minquan, Zhecheng and Luyi, groundwater is characterized by low renewal rates of less than $2 \%$ /a. Between high and low renewal rates groundwater, the renewal rate is from $2 \% /$ a to $4 \% / a$. The above distribution law of renewal rate in shallow groundwater just shows a good match with the hydrogeology settings in the study area. The high renewal rates of groundwater are just distributed mostly in the recharge areas of groundwater while low renewal rates are distributed in the discharge areas. In pediments of mountains in the west, groundwater receives lateral recharge from mountain areas while groundwater in the two laterals of the Yellow River receives lineal recharge from Yellow River. Otherwise, the main lithology of the aquifer media is sand and sandy gravel which are coarse enough and easy to be recharged by precipitation in the pediments of Taihang Mountain, Funiu Mountain and Songqi Mountain. In addition, the above areas also have a relatively high hydraulic gradient of 1/1000 1/1500 and high hydraulic conductivity of $700 \sim 1000 \mathrm{~m}^{2} / \mathrm{d}$. In the discharge areas with low renewal rates, the main lithology of the aquifer media is sandy loam, clay, and mediumfine sand with a low hydraulic conductivity of 50 300 $\mathrm{m}^{2} / \mathrm{d}$ and low hydraulic gradient of 1/4000 1/6000 (The NO. 1 Hydrogeological Party in Bureau of Geology and Mineral Resources in Henan Province, 1987).

It is evident from the isogram of renewal rate (Fig. 5) that the groundwater in Xinxiang, Zhengyang and Xixian is also located in the recharge area, but it is characterized with extremely low renewal rate of less than $1 \% / \mathrm{a}$. This suggests that the groundwater has a weak renewability influenced by over pumping of groundwater as discussed above.

In addition, the areas with high groundwater renewal rates (greater than $4.0 \% / a)$ and low groundwater renewal rates (smaller than $2 \% / a$ ) are $41 \%$ and $23 \%$ of the whole subsystem area respectively in the northern groundwater system. Moreover, the areas with the high and low groundwater renewal rates are $41 \%$ and $19 \%$ of the subsystem area respectively in the central groundwater system. The areas with the high and low groundwater renewal rates are $71 \%$ and $9 \%$ of the subsystem area respectively in the southern groundwater system. The above evidence indicates that the groundwater renewability in southern groundwater system is stronger than that in the other two systems. This results from the following two reasons. One is that the annual precipitation has a decrease trend from south to north in Henan Plains. It is $1000 \sim 1300 \mathrm{~mm}$ in the south of Huaihe River which is about two times of that in the north areas of Henan Plains. The other is that the groundwater hydraulic gradient $(1 / 2500)$ in the southern groundwater system is greater on average than that in the other two systems. The hydraulic gradients are 1/3500 and 1/4000 in the northern and central groundwater systems respectively. Therefore, the shallow groundwater in the southern groundwater system can not only get more recharge from precipitation but also have a relatively greater flow rates than groundwater in the other two groundwater systems. These all contribute to the greater renewability of shallow groundwater in the southern groundwater system.

\section{Renewal rate as an indicator on groundwater pumping}

Considering that the groundwater is characterized as higher renewal rate (more than 4\%/a) in the pediments of Taihang Mountain, Songqi Mountain, Funiu Mountain, Dabie Mountain and Weishi, Zhoukou, Xiangcheng, Luohe, Runan, Pingyu, the volume of groundwater pumping can be increased. Especially before rainy periods (from July to September), enough space in aquifer could be provided by increasing pumping so as to accept more recharge of precipitation in rainy periods. The groundwater renewal rate is more than 4\%/a near the Yellow River. Therefore, we can also make good use of the characteristics of ground suspended river of the Yellow River to induce much more river water by increasing the volume of groundwater pumping near the Yellow River. By doing so, not only more recharge from the Yellow River is induced, but also the highly turbid waters of the Yellow River may be refined by flowing through the aquifer. In addition, groundwater pumping should be reduced because of weak renewability (the renewal rate less than $2 \% / a)$ in Nanle, Puyang, Shangqiu, Luyi in order not to cause some environmental problems such as regional groundwater level decline, and land subsidence. Groundwater pumping should be restricted in Fanxian, Xinxiang Yongcheng, Zhengyang, and Xixian in order to avoid the deterioration of land subsidence, because the renewal rates of groundwater are less than 1\%/a. In other places not mentioned above in study area, groundwater pumping can be kept at current extraction rates. 


\section{Conclusions}

Tritium concentrations in groundwater and reconstructed ${ }^{3} \mathrm{H}$ concentration time series from 1953 2009 in precipitation can be used to determine the annual groundwater renewal rate. It has been demonstrated, based on the spatial distribution of groundwater renewal rate, that groundwater in the study area are classified into four groups. They are high renewal rate (more than 4\%/a) areas, moderate renewal rate $(2 \sim 4 \% / a)$ areas, low renewal rate $(1 \sim 2 \% / \mathrm{a})$ areas and extremely low renewal rate (less than 1\%/a) areas. The high renewal rate groundwater is located mainly in the recharge areas, such as the pediments of mountains and nearby the Yellow River. This group highlights the significant roles of lateral runoff from the pediment of mountains and lineal recharge of Yellow River water to two lateral ground waters. The middle renewal rate groundwater is mainly in the runoff areas. Low renewal rates of groundwater are located mainly in the discharge areas, such as Nanle, Puyang in the northern groundwater subsystem, east of Zhecheng, Luyi in the middle groundwater subsystem. Extremely low renewal rates of groundwater are located in Fanxian, Xinxiang, Yongcheng, Zhengyang and Xixian. This group highlights the influence of groundwater over-pumping. The distribution of groundwater renewal rate matches well with the hydrogeological settings in the study area.

The distribution of groundwater renewal rate indicates that pumping rate can be increased along the Yellow River and in the pediments of Taihang Mountain, Songqi Mountain, Funiu Mountain, Dabie Mountain and Weishi, Zhoukou, Xiangcheng, Luohe, Runan, Pingyu; while the groundwater pumping should be reduced in Nanle, Puyang, east of Zhecheng, Luyi, and be restricted in Fanxian, Xinxiang, Yongcheng, Zhengyang and Xixian. Other places not mentioned above in study area can keep the current pumping rate.

Acknowledgments-The research was financially supported by Geology and Mineral Technology Research Project, Department of Land and Resources, Henan Province (Land and Resources Research [2006] No. 16). The authors would like to thank the journal editors and the reviewers, their comments help to improve the paper considerably. We are also thankful to the staff at Institute of Geological Environment Monitoring of Henan Province for their assistance in the field.

\section{REFERENCES}

Ba, Q. and Xu, Y. (2010) Input function and simulated distributions of tritium in the North Pacific. Sci. China: Earth Sci. 53(3), 441-453.

Celle-Jeanton, H., Gourcy, L. and Aggarwal, P. K. (2001) Reconstruction of tritium time series in precipitation. International Conference: Study of Environmental Change Using Isotope Techniques, 430-432.
Clark, I. D. and Fritz, P. (1997) Environmental Isotopes in Hydrogeology. Lewis Press, New York, $328 \mathrm{pp}$.

Cui, Y., Zhang, G. and Shao, J. (2004) Classification and characteristics of groundwater system in the Yellow River basin. Resour. Sci. 26(2), 2-8 (in Chinese with English abstract).

Doney, S. C., Glover, D. M. and Jenkins, W. J. (1992) A model function of the global bomb tritium distribution in precipitation, 1960-1986. J. Geophys. Res.-Oceans 97(C4), 54815492.

Edmunds, W. M., Fellman, E., Goni, I. B. and Prudhomme, C. (2002) Spatial and temporal distribution of groundwater recharge in northern Nigeria. Hydrogeol. J. 10, 205-215.

Flint, A. L., Flint, L. E., Kwicklis, E. M., Fabryka-Martin, J. T. and Bodvarsson, G. S. (2002) Estimating recharge at Yucca Mountain, Nevada, USA: comparison methods. Hydrogeol. J. 10, 180-204.

Gao, S. (2008) Groundwater cycle pattern and renewability evaluation of groundwater in the Quaternary aquifer in Henan Plain. Dr. Sci. Thesis, Jilin Univ., 143 pp. (in Chinese with English abstract).

Gat, J. R., Mook, W. G. and Meijer, H. A. J. (2000) Atmospheric water. Envrionmental Isotopes in the Hydrological Cycle 2 (Mook, W. G., ed.), 63-74, UNESCO (United Nations Educational, Scientific and Cultural Organization)/ IAEA (International Atomic Energy Agency), Paris.

Gibson, J. J., Edwards, T. W. D., Birks, S. J., St. Amour, N. A., Buhay, W. M., McEachern, P., Wolfe, B. B. and Peters, D. L. (2005) Progress in isotope tracer hydrology in Canada. Hydrol. Process. 19, 303-327.

Guan, B. (1986) Numerical calculation of tritium in precipitation in China. Hydrogeol. Eng. Geol. 13(4), 38-41 (in Chinese).

Institute of Geological Environment Monitoring of Henan Province (2006) Investigation and Evaluation of Groundwater Environment in Henan Province. Zhenzhou, 111 pp. (in Chinese).

Institute of Geological Survey of Henan Province (2007) Environmental Geological Survey in Huaihe River Basin (Henan Section). Zhenzhou, 360 pp. (in Chinese).

Lan, Z. and Liu, Y. (2005) Sustainable development and utilization of shallow groundwater resources in North Henan Plain. Groundwater 27(4), 229-231 (in Chinese with English abstract).

Le Gal La Salle, C., Marlin, C., Leduc, C., Taupin, J. D., Massault, M. and Favreau, G. (2001) Renewal rate estimation of groundwater based on radioactive traces $\left({ }^{3} \mathrm{H},{ }^{14} \mathrm{C}\right)$ in an unconfined aquifer in a semi-arid area, Iullemeden Basin, Niger. J. Hydrol. 254, 145-156.

Lian, Y. (1990) A multiple linear regression statistical method for reconstructing the yearly average tritium content in precipitation. Carsologica Sinica 9(2), 157-166 (in Chinese with English abstract).

Longinelli, A. and Selmo, E. (2003) Isotopic composition of precipitation in Italy: a first overall map. J. Hydrol. 270, 75-88.

Lykoudis, S. P., Argiriou, A. A. and Dotsika, E. (2010) Spatially interpolated time series of $\delta^{18} \mathrm{O}$ in Eastern Mediterranean precipitation. Global Planet. Change 71, 150-159. 
Ma, Z. and Hou, G. (2005) Application of the technique of environmental isotope to the recharge of regional groundwater resource. Geotech. Investigation Surv. 5, 21-24 (in Chinese with English abstract).

Miao, J. (2010) Formation of the shallow groundwater in the Northern Henan Plain based on isotope ananlyses. Hydrogeol. Eng. Geol. 37(4), 5-11 (in Chinese with English abstract).

Ministry of Water Resources Division, Nanjing Hydraulic Research Institute (2004) China in the Early 21st Century, Development and Utilization of Groundwater Resources. China Waterpower Press, 315 pp. (in Chinese).

Shaw, B. R. (1977) Evaluation of distortion of residuals in trend surface analysis by clustered data. Mathematical Geol. 9(5), 507-517.

Sun, L., Zhou, X., Lu, J., Kim, Y. and Chung, Y. (2003) Climatology, trend analysis and prediction of sandstorms and their associated dustfall in China. Water, Air Soil Pollut.: Focus 3(2), 41-50.

The No. 1 Hydrogeological Party in Bureau of Geology and Mineral Resources in Henan Province (1987) Research Report on Quaternary Groundwater System in Henan Plains. Zhengzhou, 93 pp. (in Chinese).

Tian, H., Wang, W., Cao, Y., Wang, Z. and Wang, J. (2007) Tri- tium age calculation of groundwater in Guanzhong Basin. J. Xian Univ. Sci. Technol. 27(3), 382-426 (in Chinese with English abstract).

Wang, H. (1991) An Introduction to Isotope Hydrogeology. Press of Geology, Beijing, 191 pp. (in Chinese).

Weiss, W. and Roether, W. (1980) The rates of tritium input to the world oceans. Earth Planet. Sci. Lett. 49(2), 435-446.

Wood, W. W. (1999) Use and misuse of the chloride-mass balancemethod in estimating ground water recharge. Ground Water 37, 2-3.

Wood, W. W. and Imes, J. L. (1995) How wet is wet? Precipitation constraints on late Quaternary climate in the southern Arabian Peninsula. J. Hydrol. 164, 263-268.

Wood, W. W. and Sanford, W. E. (1995) Chemical and isotopic methods for quantifying ground-water recharge in a regional, semi-arid environments. Ground Water 33, 458-468.

Zhang, L., Li, L. and Gong, X. (2001) The significant ecological environmental geological problems and countermeasure research on the lower course of the Yellow River in Henan Province. Henan Geol. 19(1), 71-78 (in Chinese with English abstract).

Zhang, Y., Ye, S. and Wu, J. (2011) A modified global model for predicting the tritium distribution in precipitation, 19602005. Hydrol. Process. 25, 2379-2392. 